This item was submitted to Loughborough's Research Repository by the author.

Items in Figshare are protected by copyright, with all rights reserved, unless otherwise indicated.

\title{
Updating to remain the same: Habitual new media [Book Review]
}

PLEASE CITE THE PUBLISHED VERSION

https://doi.org/10.1177/1461444816683947a

PUBLISHER

(C) The Authors. Published by SAGE Publications (UK and US)

VERSION

AM (Accepted Manuscript)

PUBLISHER STATEMENT

This work is made available according to the conditions of the Creative Commons Attribution-NonCommercialNoDerivatives 4.0 International (CC BY-NC-ND 4.0) licence. Full details of this licence are available at: https://creativecommons.org/licenses/by-nc-nd/4.0/

\section{LICENCE}

CC BY-NC-ND 4.0

\section{REPOSITORY RECORD}

Natale, Simone. 2019. "Updating to Remain the Same: Habitual New Media [book Review]". figshare. https://hdl.handle.net/2134/24622. 
Wendy Hui Kyong Chun, Updating to Remain the Same: Habitual New Media. Cambridge, Mass.: MIT Press, 2016. Xiv + 246 pp. ISBN 9780262034494, \$32.00 (hardcover)

Reviewed by: Simone Natale, Loughborough University, UK

Within the broad field of scholarship on new media, Wendy Hui Kyong Chun’s works distinguish themselves for the way they bring together theoretical and technical insight. Chun's background in Systems Design Engineering emerges as strongly as her humanities background, and it is especially this combination that has made her writings so compelling and significant for the field. In her latest book, Updating to Remain the Same: Habitual New Media, this characteristic feature emerges in the contents as well as in the form, with the short introductory sections before each chapter being formatted like comments in programming language. This simple graphic solution is a message to the reader: the text not only focuses on digital technologies, but has the ambition to move across them.

Building on Chun’s previous works on software (2011) and digital surveillance (2006), the book looks at new media through an unusual lens: habit. It argues that "new" media matter the most when they become invisible, as an integral part of everyday life. This is not in itself an original idea: it has been argued in much of the literature on media obsolescence and technological change (e.g. Acland, 2007; Striphas, 2009). Yet, it is the extent to which Chun takes serious the notion of habit, that constitutes the strongest contribution of her book. Exploring its potential meanings and implications through a plethora of theoretical insights, from Pierre Bourdieu to John Dewey and passing through popular literature such as Duhigg's theory of the "habit loop," Chun takes the concept of habit as a point of departure for exploring various issues such as the logics of the network, friending, and online shaming. She argues that habit is being increasingly understood as 
addiction, which leads to the continuing need for new media to trigger change - to be “updated to remain the same,” as the book’s title goes. Perhaps with an excess of mathematical certainty, she proposes that Habit + Crisis = Update, or in other words, that our certainties are endlessly challenged by the impact of Internet and digital media in our societies and everyday life, which in turn makes change inherent to their functioning.

The book unfolds through four main chapters divided into two parts. The first part focuses on the issue of the network, examined both as a technical object and as a discursive construction. Chun starts by asking why networks have become a universal concept, employed to explain and describe virtually everything. She answers that networks are central to the dynamics and the imaginary of neoliberalism, whereby individuals are increasingly understood as collectively dissolving society. Moving away from such model, Chun proposes that we need to imagine networks in a different way, in terms of habitual connections that (since Habit + Crisis $=$ Update) embody in themselves the logics of repetition as well as the possibility for differentiation and interruption. In the second part, the book moves to questioning online social practices such as friending and online shaming. Chun argues that social media and the practice of friending turn the Internet into a series of gated communities whose leakiness put users in danger precisely when they believe to be safe. To the resulting confusion between public and private space Chun opposes events and performances that undermine this logic by making it most evident, such as flash mobs and spam. Finally, the book turns to examining cases of online bullying, concluding that we need to move away from the notion that everyone is exposed and towards an acknowledgment of the right not only to be forgotten, but also not to be stored in the first place.

Updating to Remain the Same is an ambitious book that builds theory through a perceptive examination of technical and social phenomena related to the Internet and digital media. It contributes to approaches that discuss and reformulate new media's relationship 
with obsolescence and memory (see Natale, 2016), proposing habit as a mechanism that inhabit new media and shape our relationship with them. Chun's approach, moreover, makes a compelling case for the opportunity to reconcile media studies' growing focus on material culture and infrastructure with an examination of the discursive practices and the imaginary constructions that also characterize media as cultural things. As she convincingly demonstrates, networks should be regarded at the same time as technical infrastructures and as ideas, conceptual frameworks that enable particular understandings of the relationship between individuals, technologies, and societies. Investigating their material nature should not count as alternative, but rather complementary to an inquiry of their discursive configurations.

The impressing breadth of the book's contributions is, overall, the source of its strength, but also of its limits. In her analysis, Chun opens numerous pathways that are at times hard to reconcile with the overall thesis, leaving the impression that a more limited focus would have resulted in an even stronger contribution. Yet, readers will find many clever and thought-provoking insights that, as an all, make the book a useful and inspiring reading for scholars interested in new media, cultural approaches to software, Internet studies, and social media.

\section{References}

Acland, C. R. (2007). Residual media. Minneapolis: University of Minnesota Press.

Chun, W. H. K. (2008). Control and freedom: Power and paranoia in the age of fiber optics. mit Press.

Chun, W. H. K. (2011). Programmed visions: Software and memory. Cambridge, Mass.: MIT Press. 
Natale, S. (2016). There Are No Old Media. Journal of Communication, 66(4), 585-603. http://doi.org/10.1111/jcom.12235

Striphas, T. G. (2009). The late age of print: Everyday book culture from consumerism to control. New York: Columbia University Press.

Author information

Dr Simone Natale

Lecturer in Communication and Media Studies

Department of Social Sciences

Loughborough University

Leicestershire LE11 3TU

United Kingdom

Email: s.natale@lboro.ac.uk

Phone: +44 (0)1509 223380

ORCID: 0000-0003-1962-2398 